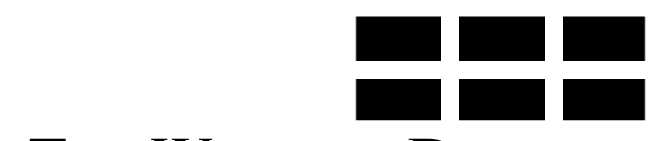

THE WILLIAM DAVIDSON INSTITUTE AT THE UNIVERSITY OF MICHIGAN BUSINESS SCHOOL

\title{
INHERITED LABOUR HOARDING, INSIDERS AND EMPLOYMENT GROWTH. PANEL DATA RESULTS: POLAND, 1996-2002.
}

\author{
By: Kate Bishop and Tomasz Mickiewicz
}

William Davidson Institute Working Paper Number 593

July 2003 
Tomasz Mickiewicz," Chris Gerry," Kate Bishop"

INHERITED LABOUR HOARDING, INSIDERS AND EMPLOYMENT GROWTH. Panel Data Results: Poland, 1996-2002.`

- SSEES University College London, Senate House, Malet St., London WC1E 7HU, E-mail: t.mickiewicz@ssees.ucl.ac.uk

* SSEES University College London, Senate House, Malet St., London WC1E 7HU, E-mail: c.gerry@ssees.ucl.ac.uk

- Office for National Statistics, 1 Drummond Gate, London SW1V 2QQ, E-mail: kate.bishop@ons.gsi.gov.uk

\begin{abstract}
Using panel data pertaining to large Polish (non-financial) firms this paper examines the determinants of employment change during the period 1996-2002. Paying particular attention to the asymmetry hypothesis we investigate the impact of own wages, outside wages, output growth, regional characteristics and sectoral affiliation on the evolution of employment.

In keeping with the 'right to manage' model we find that employment dynamics are not affected negatively by alternative wages.

Furthermore, in contrast to the early transition period, we find evidence that employment levels respond to positive sales growth (in all but state firms). The early literature, (e.g. Köllö, 1998) found that labour hoarding lowered employment elasticities in the presence of positive demand shocks. Our findings suggest that inherited labour hoarding may no longer be a factor.

We argue that the present pattern of employment adjustment is better explained by the role of insiders. This tentative conclusion is hinged on the contrasting behaviour of state and privatised companies and the similar behaviour of privatised and new private companies. We conclude that lower responsiveness of employment to both positive and negative changes in revenue in state firms is consistent with the proposition that rent sharing by insiders is stronger in the state sector.
\end{abstract}

\title{
KEY WORDS: EMPLOYMENT, TRANSITION, ASYMMETRY, OWNERSHIP, INSIDERS \\ JEL Classification: C23, J23, P31
}

\footnotetext{
^ This research was financed by the European Commission Framework 5 Project, "Regional Labour Market Adjustment in the Accession Candidate Countries" (ACCESSLAB).
} 


\section{INTRODUCTION}

In a macroeconomic context characterised by $5 \%$ economic growth but $20 \%$ unemployment (Poland, 2004, $1^{\text {st }}$ quarter) the issue of employment determination assumes particular importance. Using detailed firm level panel data relating to large Polish firms between 1996 and 2002, we concentrate on examining potential micro determinants of employment growth in Poland. We motivate our investigation with reference both to the existing economics literature on firm behaviour as well as to the Polish context. Research in the early years of transition reflected the view that state firms, faced by soft budget constraints, would not be willing to eliminate the excessive levels of labour hoarding inherited from the socialist period, and hence the quantity side of the labour market would exhibit inertia. Add to this the fact that employees held actual or effective control rights to many enterprises and the expectation of insider dominated outcomes was of particular concern. In this context, the observed enterprise adjustments that did occur were viewed by some as surprising. Firms did respond to output shocks by downsizing labour and wages. These adjustments reflected the imposition of hard budget constraints, across all ownership groups.

As the privatisation process has become embedded and the industrial structure more consolidated, later research (Grosfeld and Nivet, 1997) has pointed to considerable heterogeneity in enterprise responses. Indeed, behaviour has been described as being dependent on ownership, firm size, local labour market conditions and the nature of 'shock' experienced. Still more recent research has developed certain of these themes further (Christev and Fitzroy, 2002).

We draw on, but extend, the existing literature and provide an updated account of the micro foundations of labour demand and the evolving structure of corporate governance in Poland. Our contribution is fourfold. First, we take a new and robust approach to capturing the important heterogeneity among firms' responses to output shocks and relate this to several characteristics of interest. Second, we provide new evidence regarding the persistence of insider influence. Third, in using more recent data, we are able to comment on the continuation or otherwise of a variety of 'stylised facts' emerging from the earlier literature and, in so doing, provide a contemporary insight into the determinants of labour demand in large Polish firms. Finally, we hint at an alternative interpretation of the role of outside options and surmise that location may play a subtler role than that reflected simply in the local labour market. 
We find that a) previous employment and internal wage levels influence current employment in the anticipated way; b) the asymmetrical effects on employment of positive and negative shocks, found in earlier empirical studies disappear, suggesting that inherited labour hoarding is no longer a general problem; c) revenue growth is positively related to employment growth in both privatised and new private firms but not among state firms - pointing towards the persistence of insider power in such firms; d) similarly, employment sensitivity to negative revenue shocks is lower in the state sector e) the development of the regional infrastructure is positively associated with employment growth, suggesting a different interpretation of the effects of standard outside regional variables may be necessary.

We proceed as follows. Section 2 provides an outline review of the most relevant literature. Section 3 describes our econometric approach. In section 4, following a discussion of the data, we detail our various empirical specifications. Section 5 presents the results and relates them to our central hypotheses and section 6 concludes the paper. 


\section{RELEVANT LITERATURE}

\subsection{Theoretical framework}

There is a long history of both theoretical and empirical literature relating to aspects of employment behaviour in various categories of enterprise, in various countries, at various times. The transition process has provided a new and fertile ground for such studies. In this section we reflect briefly on the literature most relevant to our investigation. In doing this we motivate a series of testable hypotheses and provide a context within which to understand our findings ${ }^{1}$.

Our main focus in this paper is on the link between corporate control characteristics and the employment behaviour of firms. This can be analysed within the context of at least three different theoretical models. We elaborate on them briefly below though make no claim to testing differences between the models. ${ }^{2}$ Rather, for our purposes, they motivate parallel conclusions regarding the possible indicators of insiders' positions within an empirical framework of employment equations.

First, the issue of 'insider control' can be analysed within the classical framework of the literature on employee control (Ward (1958); Vanek (1970); Ireland and Law (1982)). This is a well-rehearsed literature arguing that firms dominated by insiders have low employment responsiveness to product demand shocks. Indeed, the labour managed firm always varies employment "by a smaller amount in response to given price changes than do their capitalist counterparts" (Laidler and Estrin, 1989). Given the extent, to which state firms have been controlled by insiders in both the late socialist period and in the transition period, we expect to observe either employee control or at least the strong position of employees in the bargaining process and hence potentially lower employment adjustments to output changes ${ }^{3}$. In addition, in cases where subsequent privatisations and reforms haven't sufficiently modified the internal control structures, we may expect those effects to prevail after privatisation. From this point of view, using new private firms as a benchmark is an important empirical test.

Second, the employee ownership models can be easily incorporated as a limiting case of more recent 'efficient contract' models, best exemplified by the seminal paper of Brown and

\footnotetext{
${ }^{1}$ Appendix 1 summarises the key literature.

${ }^{2}$ For a good and accessible discussion of the problems relating to empirically testing employment determination models, see Booth (1995).

${ }^{3}$ Earle and Estrin (1996) and Köllo (1998) offer a good discussion of the insiders' control model in the context of transition economies.
} 
Ashenfelter (1986). In this class of models bargaining is always related to both wages and employment and full insider control relates to the case, in which all bargaining strength lies with labour. In addition, Brown and Ashenfelter (1986) developed three alternative scenarios derived from the impact of internal and external wages on employment. If the alternative wage acts as the sole determinant of employment, the employment contract is said to be strongly efficient ${ }^{4}$. That is, employment is set so as to equate the marginal revenue product of workers with the alternative wage. When both the internal and alternative wage are significant (negative) determinants of employment, employment determination is characterised as 'weakly efficient'. If only the internal wage is instrumental in determining employment, the outcome is consistent with a third theoretical model, that is, one of monopolistic price setting by the union and unilateral employment setting by the employer (i.e. the 'right to manage' model) ${ }^{5}$. In this case employment will be lower than under efficient contracts. Brown and Ashenfelter test these hypotheses using US data for the period 1948-65, and are unable to reject the hypothesis that contracts are 'weakly efficient' but not 'strongly efficient'.

In merging the 'right to manage' model and the efficient contract model, Oswald (1993) offers a critique. He argues that, to the extent that unions are likely to focus on wages in the bargaining process rather than on the combination of employment and wages, it is perfectly plausible that 'efficient' bargaining may produce outcomes consistent with the 'right to manage' outcome.

On a related theme, an interesting implication stemming from Oswald's (1993) analysis, and consistent with insider ownership/control is that the employment response may be weak or even negative in response to a positive demand shock. That is, we expect to observe asymmetry of outcomes in response to positive and negative demand shocks. The underlying motivation for the asymmetry hypothesis can be traced back to Lindbeck and Snower (1987) yet, in the context of the transition economies, asymmetry has a specific interpretation. In particular, asymmetry may be suggestive of inherited labour hoarding. In other words, because of existing labour reserves, employment is inelastic with respect to an increase in sales, but not with respect to a decrease. Even without inherited labour hoarding, weak or even negative upward output elasticity of

\footnotetext{
${ }^{4}$ It can be traced back to the efficient bargaining model by Leontief (1946).

${ }^{5}$ Under this framework a union chooses a wage rate constrained by demand for its member's labour and, as argued by Dunlop (1944), equilibria lie on the labour demand curve. It has been termed a monopoly union as its introduction into a competitive labour market would lead to a deadweight loss usually associated with monopoly (Currie, 1991, p.46).
} 
employment remains consistent with the insider hypothesis. More generally, in the absence of an 'insiders effect' and without inherited labour hoarding we expect to observe symmetry. ${ }^{6}$

We reiterate that it is not our intention to subject these theories to testing here ${ }^{7}$ Nevertheless, to understand and interpret our results it pays to keep in mind that alternative models of bargaining can produce similar testable hypotheses. From our point of view, two critical tests come from the fact that /i/ we expect employment to be less responsive in insider dominated companies, and /ii/ if, additionally, there is still asymmetry in response to negative and positive shocks, this can be viewed as an indicator that the legacy of socialist labour hoarding may still impact upon firm behaviour.

\subsection{Empirical findings}

As appendix 1 illustrates, the early empirical evidence from the transition countries is strongly suggestive of negative wage elasticity of employment (to a declining degree as transition progresses) but there is little clear evidence relating to the outside option. For Poland, Basu et al. (2000) find own wage elasticity of -0.84 immediately after transition began; Grosfeld and Nivet present a figure of between -0.03 and -0.13 for the years 1988 - 1994; and Christev and Fitzroy (2002), using later data from 1994-1997, find wage elasticity of -0.08. For Hungary, Köllö (1998) finds elasticity declining from -0.6 to -0.3 by the start of transition. Körösi (2002), covering the period 1992-1999 for Hungary, finds that, in the initial years of transition, labour demand was much more responsive to own wages but by 1999 characteristics of employment adjustment in Hungarian firms, had converged on that of their Western counterparts. In sum, the literature suggests that own-wage elasticity coefficients peaked in the early transition period.

As witnessed by the growing body of research examining the relationship between ownership, control and employment patterns the issue of insider control manifestly relates to that of ownership. Konings et al. (1996) find evidence that, in the early transition period (i.e. pre 1991), new private firms, in which insiders are hypothesised to be less influential, contributed

\footnotetext{
${ }^{6}$ Indeed, Haskel et al., (1997) study asymmetry in the UK. They find that employment adjustment is more common in times of a positive demand shock, as compared to a negative demand shock. Thus, there is evidence of asymmetry, but reversed as compared to transition economies.

${ }^{7}$ For a thorough discussion of the theoretical models, see for instance Layard et al. (1991) and Booth (1995).
} 
significantly to Polish job growth. Basu et al. (2000) and Grosfeld and Nivet (1997) did not find significant differences in employment behaviour for different ownership sectors in the early transition period in Poland (i.e. 1990-1991), but importantly, in neither case, were new firms identified. Grosfeld and Nivet (1997) offer an explanation for the absence of differences between privatised and state firms. Specifically, half of the privatised enterprises in their sample held an explicit commitment to keep employment levels stable during the first 1.5-3 years postprivatisation. This suggests the need to examine more recent behaviour.

Faggio and Konings (2003) examine job creation, destruction and employment growth in five transition economies: Poland, Slovenia, Bulgaria, Romania and Estonia, with firm level panel data from a similar period, i.e. 1993-97. They find that, in Poland and Romania, state ownership has a negative effect on employment growth in comparison with firms under majority private domestic ownership, and that large firms in more advanced transition economies downsized faster than in the laggards. ${ }^{8}$

\subsubsection{Empirical findings on asymmetry}

Estrin and Svenjar (1998) and Köllö (1998) investigate this asymmetry hypothesis by looking at employment growth differences among firms experiencing/not experiencing declining real sales. Based on data from the early transition period (1986-9, 1989-2 and 1992-3) Köllö finds that the elasticity of labour demand is relatively high for firms with decreasing output (0.2-0.3), yet insignificant for those with increasing output. This is a finding consistent with the inherited labour surplus hypothesis. Moreover the relationship between output and employment became stronger over time, especially for privatised firms (Ibidem, p.92 and 100). Estrin and Svenjar (1998), using firm level data from 1988-1993 for Poland, Czech Republic, Slovak Republic and Hungary, also test the asymmetry hypothesis. Their results reveal that employment responded to both decreasing and increasing sales, but that the response was higher for firms with increasing sales: $0.36-0.44$ as opposed to $0.12-0.35$.

Christev and Fitzroy (2002) focus on Polish firms for a later period (1994 - 1997) than that covered by the above studies. They estimate an equation in first differences using GMM

\footnotetext{
${ }^{8}$ Papers on other transition countries, discussing ownership cross sections include Konings et al. (2003) on Ukraine, Rutkowski (2002) on Croatia, Brown and Earle (2002) and Konings and Lehmann (2001) on Russia, Dong (1988) and Lee (1999) on China. See summary in appendix 1.
} 
Arellano-Bond (1991) methods and split the variables for positive and negative growth of output. They find that employment growth responds only to decreasing sales and offer the interpretation that inherited labour hoarding persisted among Polish firms in that period. It is worth noting however, that the sample of these authors' did not include de novo firms, in which labour hoarding should not be observed. On the other hand, they find that state owned enterprises are characterised by a far smaller significant response to negative shocks than either the firms privatised to outsiders or firms included in the National Investment Funds programme. Again, this finding would appear to be consistent with insiders' control.

Similar results were obtained by Körősi (2002), who estimated labour demand equations annually for the period 1992-1999 for medium and large Hungarian firms. Interestingly, when the sample is restricted first to manufacturing firms, and second to engineering firms alone, the difference in employment response between firms with increasing and decreasing output seems to disappear in the most recent period. Accounting for sectoral differences may be important in so far as sectoral heterogeneity masks certain underlying trends, such as the fact that the impact of initial labour hoarding may be decreasing over time ${ }^{9}$.

Finally, size may also matter. Typically, smaller firms were more likely to be privatised and new companies are smaller by design at least in the early period. This implies a correlation between size and ownership, which may affect the robustness of conclusions. Several studies tackle this issue directly. Köllő (1998) controls for small and large firms. His results for Hungarian firms reveal that small firms are characterised by stronger employment growth. Similarly, Faggio and Konings (2003) report a clear relationship between employment growth and initial size: larger firms are negatively associated with employment growth. Christev and Fitzroy (2002) include a variable to represent average firm size and find that larger firms tend to grow more slowly. As our sample is drawn from the largest Polish firms, extrapolation of our results to small firms should be viewed cautiously.

So, what lessons can be culled from this literature to inform our examination of the employment behaviour of large Polish firms? First, if employees attach significant weight to wages in the

\footnotetext{
${ }^{9}$ This does present a potential empirical problem in the short run. While sectoral affiliation is a binary indicator, the real processes are continuous in character. The transition trend towards 'tertiarisaiton' likely relates to most postsocialist manufacturing companies without necessarily being reflected in sectoral statistics.
} 
bargaining process then we should observe a negative correlation between employment and internal wages and thus can reject the 'strong efficiency hypothesis'. Second, if insiders maintain control over firms, we will observe low responsiveness of employment to final output. Third, since low upwards employment elasticity is also consistent with the labour hoarding story, it is both (i) low downwards elasticity and (ii) low upwards employment elasticity, which are indicative of a strong insider domination, in contrast with a situation, where only the latter holds. Finally, as a consequence of weak insider effects alongside an absence of residual labour hoarding, de novo enterprises should exhibit a positive association between output and employment growth.

\section{Methodological Approach and Data}

\subsection{Data}

This study is based on data procured from publicly available company level information relating to Poland's largest companies. The data is sourced from a project (with participation of one of the co-authors), financed by the Polish Committee for Scientific Research (grant 1H02C-02419) ${ }^{10}$ and utilises all publicly available information on Poland's largest companies. Information is sourced from the Warsaw Stock Exchange and several lists of the 500 largest (revenue) companies published by journals and magazines, including Rzeczpospolita, Polityka, Gazeta Bankowa, Nowe Zycie Gospodarcze, Zycie Gospodarcze and Businessman. Ultimately, the veracity of the information used is verified and corrected in line with the companies' annual reports - now accessible in most cases. Our panel of firms is unbalanced since, inevitably, there are missing values for certain companies, in certain years. In addition, to limit the impact of potential measurement error, we eliminate $0.5 \%$ of observations in each tail of our key variables. $^{11}$

Apart from standard type errors, there were several other noteworthy problems encountered during data processing. In principle, Polish state companies were prevented from buying shares

\footnotetext{
${ }^{10}$ Other results of the project are available in an edited volume in Polish (Baltowski, 2002).

${ }^{11}$ On inspection, the observations in the tails cannot be explained other than as measurement errors. Typically, the inclusion of outliers makes rejecting the null hypotheses easier and inflates the coefficients upwards. These results are available from the authors on request.
} 
in other privatised companies. In reality, this applied neither to privatisations (or semiprivatisations) resulting from bank-led restructuring programmes, nor to post-privatisation ownership transfers including, for instance, companies privatised via the National Investment Funds programme. As a consequence, a number of 'privatised' companies are wrongly attributed to the private sector rather than to the state sector. These cases are not necessarily easy to detect, due to the multi-layered nature of cross-company ownership, but the data has been corrected where possible. On a related theme there are problems with distinguishing the dominant ownership class from minority owner groups. There are also cases of companies being wrongly classified as 'de novo' private companies, either because they have been formally registered as a new company as part of the privatisation proceedings, or because they are new companies created by other state-controlled firms. The former case relates in particular to companies privatised through employee buy-outs (see Mickiewicz and Baltowski, 2003). We are also aware of the fact that some sources do not distinguish between individual companies and consolidated balances of capital groups with similar names. Compiling both categories into one time series would create a serious data distortion.

In keeping with the literature we choose to use aggregate price indices to transform nominal series. In particular, following Christev and Fitzroy (2002) and Currie (1991) we use CPI since, arguably, use of PPI at sectoral level would erase some of the effects we are particularly interested in. Thus, while using the aggregate price index, we do not eliminate the impact of shifts in relative sectoral prices on total revenue. This is important because we wish the change in revenue to incorporate the impact of sectoral demand for the final product.

The construction of the ownership cross-section is far from straightforward and no approach is exempt from criticism. Though it is straightforward to identify de novo firms, since by definition they are a time invariant category, problems arise as soon as we begin to construct ownership indicators for privatised versus state companies. To reduce potential endogeneity, one approach could be to use pre-sample information on ownership to partition the data and hence treat ownership as time invariant. However, in most cases, future information pertaining to ownership was available in pre-sample time and it has been well established that the privatisation processes 
impacted upon firm behaviour prior to the formal privatisation date. ${ }^{12}$ This being so, treating ownership as pre-determined is unlikely to remove any potential endogeneity and a better option could be to distinguish between those companies, privatised during the period in question and those which were not. Yet, even then, some companies in the state group might again expect privatisation after the sample period and the impact of future expectation is not eliminated. In our specifications we utilise time variant dummy variables for our state and privatised categories, but note that estimates based on alternative ownership specifications, in line with those described above, do not affect the key results.

An appealing feature of our data is that, through the details concerning company and location, we are able to match the enterprises with corresponding administrative units and subsequently with appropriate regional labour market indicators, available from the Polish Central Statistical Office. We also adopt the public infrastructure indices, developed by Duffy and Walsh (2001) that rank voivodships according to six infrastructure indicators. ${ }^{13}$ However, assigning companies to regions created its own methodological challenges. $25 \%$ of the companies included in the sample are registered in Warsaw. These can be considered in two sub-categories: companies operating nation-wide, and those whose operations are located in the capital city. $9 \%$ of companies, typically in manufacturing production, are in the latter category. The remaining enterprises registered in Warsaw (16\% of the sample) we consider to be nation-wide, typically consisting of trade companies and retail network firms, but also producers with several major sites. We attribute national averages of the relevant labour market indicators in the case of those companies labelled nation-wide.

The above caveats aside our firm level data is relatively rich and concentrates on the largest Polish firms. We have reliable information on employment levels, wage levels, total earnings, ownership status and the sector of activity supplemented with information on regional wages, sectoral wages, unemployment and public infrastructure. Appendix 2 provides full variable definitions while Table 1 provides descriptive statistics for the key variables.

\footnotetext{
${ }^{12}$ See Megginson and Netter (2001) for further discussion on methodology.

${ }^{13}$ These indicators relate to the number of telephones, fax machines, railways and public roads in the region as well as the urban share of the population and the share of services in total regional employment.
} 
Table 1: Descriptive statistics, $1998-2002: 25^{\text {th }}, 50^{\text {th }}$ and $75^{\text {th }}$ percentiles.

\begin{tabular}{|l|r|r|r|}
\hline Category & $\begin{array}{c}\text { ANumber of } \\
\text { employees }\end{array}$ & $\begin{array}{c}\text { A Real } \\
\text { wage }\end{array}$ & $\begin{array}{c}\text { A Real total } \\
\text { revenue }\end{array}$ \\
\hline \hline All companies & $-10.2 \%$ & $-4.1 \%$ & $-9.5 \%$ \\
& $-2.4 \%$ & $1.7 \%$ & $1.9 \%$ \\
& $1.3 \%$ & $6.1 \%$ & $10.1 \%$ \\
\hline State firms & $-8.5 \%$ & $-3.0 \%$ & $-9.9 \%$ \\
& $-2.4 \%$ & $1.7 \%$ & $* *-0.8 \%$ \\
& $-0.3 \%$ & $4.6 \%$ & $7.0 \%$ \\
\hline Privatised firms & $-16.9 \%$ & $-5.8 \%$ & $-11.3 \%$ \\
& $* * *-4.2 \%$ & $1.7 \%$ & $\dagger-1.2 \%$ \\
& $2.1 \%$ & $9.4 \%$ & $11.1 \%$ \\
\hline De novo firms & $-7.4 \%$ & $-7.0 \%$ & $-5.5 \%$ \\
& $* * * 1.4 \%$ & $1.4 \%$ & $* * * 5.1 \%$ \\
& $12.4 \%$ & $9.4 \%$ & $18.6 \%$ \\
\hline Companies in regions with poor & $-8.6 \%$ & $-3.8 \%$ & $-8.3 \%$ \\
infrastructure (I-IV) & $-2.3 \%$ & $1.7 \%$ & $1.4 \%$ \\
& $0.2 \%$ & $5.5 \%$ & $9.8 \%$ \\
\hline Companies in regions with average & $-14.9 \%$ & $-4.9 \%$ & $-11.6 \%$ \\
infrastructure (V) & $*-3.1 \%$ & $1.7 \%$ & $* *-1.7 \%$ \\
& $-0.2 \%$ & $5.6 \%$ & $7.5 \%$ \\
\hline Companies in regions with best & $-10.2 \%$ & $-4.4 \%$ & $-0.8 \%$ \\
infrastructure (VI) & $-2.5 \%$ & $1.8 \%$ & $0.7 \%$ \\
& $2.2 \%$ & $7.3 \%$ & $10.0 \%$ \\
\hline Companies with several major locations & $-8.4 \%$ & $-7.8 \%$ & $-11.2 \%$ \\
nation-wide & $*-0.6 \%$ & $1.0 \%$ & $\dagger 2.2 \%$ \\
& $10.6 \%$ & $8.6 \%$ & $16.9 \%$ \\
\hline
\end{tabular}

Notes:

(1) The numbers given in each cell are $25^{\text {th }}, 50^{\text {th }}$ and $75^{\text {th }}$ percentiles respectively.

(2) For computational ease, percentage changes are approximated by logarithmic differences.

(3) *** Significant at $0.001 ; * *$ Significant at $0.01 ; *$ Significant at 0.05 ; † Significant at 0.1 . Significance levels relate to Pearson $\chi^{2}$ (continuity corrected) based on the non-parametric test on the equality of medians.

Interestingly, in terms of both revenue and employment dynamics, the performance of state companies is superior to their privatised counterparts possibly as a result of post-privatisation restructuring. The main difference however seems to be between these two groups and de novo firms, for which the growth of both employment and output is high, and the difference with the two other categories is highly significant. It is also worth noting that for the state firms, the distribution of the percentage change in employment seems to have more mass in the centre, as 
compared with the other categories. This is illustrated by lower absolute values at both the $25^{\text {th }}$ and $75^{\text {th }}$ percentiles. Thus, even at this preliminary stage of analysis we detect lower responsiveness of employment levels in state sector firms. The pattern related to the quality of infrastructure in a firms locality is not clear cut. Interestingly however, companies operating nation-wide exhibit better performance than the rest of the sample, in terms of both employment and revenue dynamics.

\subsection{Econometric Techniques and Specification}

To explore the hypotheses outlined above we employ generalised method of moments techniques (GMM). In their seminal paper, Arellano and Bond (1991) find that GMM is superior to instrumental variable estimators and recommend one step GMM for inference (Ibidem, p.293). More recently, Judson and Owen (1999) support the conclusion that this estimation method is superior to feasible alternatives for unbalanced panels with a short time dimension. The GMM estimator is robust in that it does not require information pertaining to the exact distribution of the disturbances and is instrumental in combating the problems associated with potential endogeneity. The estimator allows for the endogeneity of all regressors by using predetermined variables as efficient instruments. In essence, this model involves estimation in differenced form of the general distributed-lag model.

We have made several informed choices in our specification of the model and comment upon these briefly. Firstly, following Arellano-Bond methodology, we transformed variables into first (logarithmic) differences to alleviate possible problems relating to individual fixed effects. Secondly, in view of the relatively small sample size, we adopt a conservative approach in our choice of ownership categories. We focus our attention on the three ownership categories - state, privatised and de novo - described in appendix 2. Our key indicator of the enterprises financial position is the revenue growth experienced by the firm - a variable we interact in various ways to investigate the hypotheses outlined in the previous section.

We estimate the following basic specification: 
semployment $_{i t}=\Delta$ semployment $_{i t-1}+\Delta r e a l_{-}$wage $_{i t}+\Delta$ real_revenue $_{i t}+\Delta r e a l_{-}$sec toral_wage ${ }_{i t}$

$+\Delta$ real_regional_wage $i t+Z_{\gamma}+\sum O_{i t}+\sum S_{i t}+\sum T_{t}+v_{i t}$

where $O_{i t}, S_{i t}$ and $T_{i t}$ relate to ownership, sectoral and time controls respectively and $\boldsymbol{Z}$ is a matrix of interactive effects with a corresponding column vector of coefficients $\boldsymbol{\gamma}$. As the variables are first-differenced, the inclusion of sectoral controls is not a necessity, as individual unobservable effects are taken care of, however we follow here the practice of some other researchers (Christev and FitzRoy (2002) in particular).

We estimate equation (1) without ownership and interactive effects and report our results in column 1, Table 2. Specification (2) introduces the first ownership test by interacting both revenue growth and wage growth with the dummy for state ownership. In the specifications (3)(7), we drop the wage interactive term and introduce a differential slope coefficient, taking the value 0 for firms with positive revenue growth and the actual value of the negative revenue change for the remaining firms. This specification enables an initial test for signs of asymmetry. This term is then interacted with ownership dummies to further explore dimensions of asymmetry. That is, we are able to investigate the asymmetry hypothesis without dividing the sample into sub-groups. We then modify the composition of outside controls to obtain specifications (3)-(7). Specifically, specification (4) omits sectoral wages; specification (5) introduces regional infrastructure effects, including a dummy variable for firms operating in multiple locations; specification (6) retains the infrastructure controls at the expense of regional wages; and specification (7) retains the dummy for multiple location, drops the other infrastructure dummies and reintroduces a control for the regional wage. Finally we carry out two additional tests. Specification (8) introduces differential effects for de novo firms, enabling us to detect differential slope coefficients for all three ownership groups and to assess the difference between new private firms and privatised firms, in addition to the difference between the state sector and the aggregate private sector. Specification (9) retains controls and interactive effects for both state and de novo firms, but eliminates variables relating to asymmetry. In short, (9) is a specification similar to the basic specification (2), but distinguishing between all three ownership groups, to establish whether our focus on the private-state nexus was justified. 


\section{Results}

As expected, the lagged dependent variable is positive and significant, with the corresponding coefficient taking values between 0.22 and 0.29 in alternative specifications. This result reflects a somewhat smaller effect than Christev and Fitzroy (2002) who cover similar firms in an earlier period and obtain an estimated coefficient of 0.7 on lagged employment growth. Both cases suggest that employment growth is path dependent and that the empirical approach taken is therefore appropriate. The internal wage is negatively significant with a coefficient varying narrowly between -.57 and -.60 across the specifications. Higher internal wage growth is associated with lower employment growth and the 'strong efficiency' hypothesis is clearly rejected. The size of the effect is higher than that found by both Christev and Fitzroy (2002) and Grosfeld and Nivet (1997), but lower than that found by Basu et al. (2000). Turning to outside options we find that sectoral wages and regional wages are positive but that only the latter are significant ${ }^{14}$. According to the 'weak efficiency' hypothesis the outside wage available to workers should be negatively related to employment change but, just as Brown and Ashenfelter (1986) found it "frequently positively related to employment" so too do we. It would seem to be the case that higher regional wages may reflect some factor other than the bargaining relations of firms and employees. This is a theme to which we return later. In terms of total revenue change we find a positive relationship with employment change, suggesting that output expansions are being transformed into employment growth as opposed to only wage growth. For the whole sample (Table 2, specification (1)), the output elasticity of employment is 0.28 , which is entirely consistent with other studies for both Poland and Hungary (Basu et al. (2000), Köllö (1998), Grosfeld and Nivet (1997)).

We turn now to ownership effects. The ownership dummies reveal that, compared to privatised and de novo firms, state sector firms have significantly lower employment growth, and the result is consistent across the specifications. This is as we would expect. On the other hand, we are unable to detect any effect related to the difference between de novo and privatised firms (Table 3, specifications (8) and (9)).

The sectoral controls point towards higher employment growth in the utilities sector and lower employment growth for the mining \& heavy industry and construction sectors. We have particular confidence in the robustness of these results since not only are they consistent across 
specifications but they are also based on orthogonal contrasts rather than reflecting simple sectoral dummies. In particular, the poor performance of employment in the mining and heavy industry sector is consistent with the prior knowledge.

In specification (2) we add additional controls, interacting state ownership with both the own wage and total revenue. The results demonstrate the existence of clearly differing dynamics depending on ownership status. The negative association of the state/revenue interactive term shows that revenue growth in state firms translates into far lower employment growth than in other firms. This is consistent with either an interpretation of excess 'inherited labour' or of insiders appropriating rent in the form of wages as enterprise revenues grow. The latter explanation garners support from the fact that wage increases in state firms are more weakly associated with employment declines than is the case for other firms ${ }^{15}$. Taken together these two findings imply some element of 'insider control' in state firms.

Table 3 reports the results of our investigation of the asymmetry hypothesis. In specification (3), we estimate a version of specification (1) with the inclusion of a differential slope coefficient identifying the level of revenue change among firms experiencing declines in revenue. We also interact this term with the state sector dummy. We find the former coefficient to be negative but insignificant, suggesting that for negative revenue growth firms, the employment with respect to sales elasticity is lower than that predicted by the aggregate relationship incorporating the positive revenue growth firms. This is indicative of a general asymmetry effect - namely that employment is more responsive upwards than downwards - though the general asymmetry effect appears weak. This is potentially important since it diverges from the findings of earlier periods. For example, Christev and Fitzroy (2002) find that sales increases have little effect on employment growth whereas employment does respond to falling sales. Similar results were obtained by Köllö (1998) for the early transition period in Hungary. For the early transition period, this was interpreted as evidence of high levels of initial labour hoarding enabling firms to expand output without increasing employment. In so far as such an interpretation is correct, our findings go some way to establishing that the initial 'widespread labour hoarding' may be over. Hence, when firms experience a positive demand shock they are inclined to adjust their labour

\footnotetext{
${ }^{14}$ We also experimented with a regional unemployment measure but found that to be highly insignificant.

15 .It should be noted however that this differential effect is marginally insignificant.
} 
force accordingly. It is only in the state sector, where output elasticity is generally dramatically lower, that we still observe the response to output decline being stronger than that to the output increase. But even in state sector firms, the difference is no longer significant. To see if our conclusions are robust we experiment with alternative sets of outside options in specifications (3)-(7) and find that our asymmetry results hold.

In specification (8) we introduce additional effects for de novo firms. Output elasticity of employment is stronger in privatised companies than in de novo companies where the output growth is positive, but the differences between the two groups are not significant. It is interesting to contrast that conclusion with the analysis based on descriptive statistics presented earlier. The highly significant and positive difference in the employment growth of de novo firms compared with other sectors, vanishes once we subject it to a multivariate approach and control for endogeneity using the GMM Arellano-Bond framework. Once more, the main difference is that for state firms with positive employment growth, the increase in employment for a given change in revenue is lower than for other firms. Taken together, this implies that expanding firms do indeed turn revenue growth into higher employment but that state firms do so at a lesser rate. In comparison, negative revenue growth per se does not imply anything for employment growth but again, among state owned firms, negative revenue growth is associated with lower employment elasticities compared with other sectors.

Christev and Fitzroy (2002), separating their sample into firms with positive and negative sales growth, conclude that there is no evidence of a 'significant positive employment response to positive sales growth'. This is taken as evidence of continuing labour hoarding. Our results offer a more optimistic interpretation of the progress of enterprise restructuring in Poland. In particular our more recent data reveals clear evidence that a strong positive response to revenue growth has emerged in large Polish firms, yet only in the private sector. For state owned firms the effect is significantly weaker and close to zero. That is, outside of state owned firms, labour hoarding is no longer a significant impediment to employment growth. In addition, state firms with negative revenue growth also exhibit lower employment elasticities than the aggregate suggests. The latter observation is in line with Christev and Fitzroy (2002) who find that 'state owned enterprises exhibit the smallest significant response to negative shocks'. But generally, we find no significant evidence of asymmetry between firms experiencing negative as opposed to 
positive revenue growth, regardless of the ownership sector. Somewhat surprisingly, in the aggregate, it no longer fits the 'transition model'.

In fact, we find that, employment responds positively to revenue growth but less strongly to revenue falls and so is already more in keeping with western economic models (e.g. Haskel et al, 1997). Notwithstanding this, elements of an 'unreformed' state sector still persist. State firms, whether experiencing expanding revenues or otherwise, exhibit lower employment elasticities than all firms. This result hints at alternative interpretations. First, it is consistent with sustained or consolidated insider (employee) control, where firms are less likely to raise employment in response to positive shocks and to lay off workers when faced with negative shocks. Alternatively, assuming that some labour hoarding was still present in state companies, an increase in revenue may help the companies to cover the costs of redundancies while, in the absence of growth, labour shedding is not possible.

Table 3 also contains potentially important results concerning outside options. Consistent with a series of empirical studies stretching back to Brown and Ashenfelter (1986) the coefficient for regional wages is positive and significant across our specifications. The reasons for this persistent result have not been explicitly identified to date. One possible explanation is that the regional wage may be a proxy for some alternative characteristic of the regional economy associated with firm growth. To investigate whether the variable reflects regional economic performance we experimented by including a regional unemployment variable but found this to be consistently insignificant. Hence, as a first stab at investigating this important issue we include regional infrastructure variables in specifications (5) and (6). Not only are our other findings robust to this variation but we find evidence that firms in regions with the best public infrastructure have higher levels of employment growth. This is clearly of interest to policy makers. On a related issue, firms operating in multiple regions also outperform other firms. The latter finding may partially reflect a firms propensity to locate multiple branches rationally and related efficiency gains, which are transformed into employment generation. 


\section{CONCLUDING REMARKS}

Using data from a panel of large Polish firms, covering a longer and later period than other studies (e.g. Grosfeld and Nivet (1997), Basu et al., (2000) and Christev and Fitzroy (2002)) we make a series of interesting and important findings concerning firm employment behaviour. Not only does our data enable us to investigate employment determination further into the transition period but also allows us to identify de novo companies, which by the late 1990's were already appearing among Poland's largest firms.

First, we find that employment is affected by internal wages and not external wages. This may reflect monopoly price setting unions and unilateral employment setting by the employer (Brown and Ashenfelter, 1986), regardless of the ownership sector.

Second, as far as the asymmetry hypothesis is concerned, our results differ form earlier studies such as Köllö (1998) and Christev and Fitzroy (2002). We find that firms no longer only respond to a decline in real total revenue, but to a positive demand shock too, suggesting that the earlier residual labour hoarding is now over.

Third, it is clear in all specifications that firm performance (measured as growth in real total revenue $^{16}$ ) translates into employment growth. Similarly, poor performance (negative real output growth) is accompanied by lower elasticity of employment, but the difference between positive and negative growth is not significant.

The most compelling result of our analysis is that state sector firms exhibit far lower output elasticities of employment than firms in the private sector. In the case of positive output growth, the employment elasticity oscillates around zero.

Finally, our analysis offers up some crucial issues for further investigation and for policy makers to be aware of. In particular, it would seem that the quality of public infrastructure plays an

\footnotetext{
${ }^{16}$ Earnings before taxes were largely insignificant.
} 
important role in firm development. Our proxies for this characteristic are highly aggregated in this analysis but provide strong motivation for further research in this area.

Overall, our analysis offers up a clearer picture of employment determination in the later transition period. With the progress of privatisation, and the downsizing of state sector firms, visible in our results, the industrial structure is clearly still evolving and one may expect aggregate employment elasticities to increase over time. Currently Poland is experiencing high levels of unemployment and no net employment creation. Our results shed some light on the micro behaviour influencing those macro indicators. 


\section{BIBLIOGRAPHY}

Arellano, M., and S. Bond, 1991, Some tests of specification for panel data: Monte Carlo evidence and an application to employment equations, Review of Economic Studies, 58, 277-297.

Baltowski, M., ed., 2002, Przedsiebiorstwa sprywatyzowane w gospodarce polskiej, (PWN, Warszawa).

Basu, S., S. Estrin and J. Svenjar, 2000, Employment and wages in enterprises under communism and in transition: evidence from Central Europe and Russia, Working Paper, 114b, William Davidson Institute.

Booth, A., 1995, The economics of the trade union, (Cambridge University Press: Cambridge).

Brown, J., and O. Ashenfelter, 1986, Testing the efficiency of employment contracts, Journal of Political Economy, 94, 40-87.

Brown, J., and J. Earle, 2002, The reallocation of workers and jobs in Russian industry: new evidence on measures and determinants, Discussion Paper, 3663, CEPR.

Burgess, S., 1988, Employment adjustment in UK manufacturing, The Economic Journal, 98, 81-103.

Card, D., 1990, Unexpected inflation real wages and employment determination in union contracts," American Economic Review, 8, 669-688.

Checci, D., and G. Navaretti, 2003, Adjusting labour demand: multinational versus national firms - a cross European analysis, Discussion Paper, 3751, CEPR.

Christev, A., and F. Fiztroy, 2002, Employment and wage adjustment: insider-outsider control in a Polish privatisation panel study, Journal of Comparative Economics, 30, 251-275.

Currie, J., 1991, Employment determination in a unionised public sector labour market: the case of Ontario's school teachers, Journal of Labour Economics, 9, 45-66.

Dong, X., 1998, Employment and wage determination in China's rural industry: investigation using 1984-90 Panel data, Journal of Comparative Economics, 26, 485-502.

Duffy, F. and P. Walsh, 2001, Individual pay and outside options: evidence from the Polish labour force survey, Discussion Paper, 295, IZA. 
Dunlop, T., 1994, Wage determination under trade unions, (Macmillan, New York).

Earle, J., and S. Estrin, 1995, Alternative ownership firms: the impact on restructuring, Economic Transition, 3, 111-115.

Estrin, S., and J. Svejnar, 1998, The effects of output, ownership, and legal form on employment and wages in Central European firms, in: S. Commander, ed., Enterprise Restructuring and Unemployment in Models of Transition, (World Bank, Washington D.C.), 31-56.

Faggio, G., and J. Konings, 2003, Job creation, job destruction and employment growth in the transition countries in the 90s, Economic Systems, 27, 129-154.

Grosfeld, I., and F. Nivet, 1997, Firms' heterogeneity in transition: evidence from a Polish panel data set, Working paper, 47, William Davidson Institute.

Haskel, J., B. Kersley, and C. Martin, 1997, Labour flexibility and employment adjustment: micro evidence from UK establishments, Oxford Economic Papers, 49, 362-79.

Ireland, N. and P. Law, 1982, The economics of labour-managed enterprise, (Croom Helm, London).

Judson, R., and A. Owen, 1999, Estimating dynamic panel data models: a guide for macroeconomists, Economics Letters, 65, 9-15.

Köllö, J., 1998, Employment and wages in three stages of Hungary's transition, in: S. Commander, ed., Enterprise behaviour in models of transition, (The World Bank, Washington D.C).

Konings, J., O. Kupets and H. Lehmann, 2003, Gross job flows in Ukraine, size, ownership and trade effects, Discussion Paper, 3802, CEPR.

Konings, J., and H. Lehmann, 2001, Marshall and labour demand in Russia: going back to basics, Journal of Comparative Economics, 30, 134-159.

Konings, J., H. Lehmann, and M. Schaffer, 1996, Employment growth, job creation and job destruction in Polish industry: 1988-91, Labour Economics, 3, 299-317.

Körösi, G., 2002, Labour adjustment and efficiency in Hungary, Budapest Working Papers on the Labour Market, 2002/4, Hungarian Academy of Science. 
Laidler, D., and S. Estrin, 1989, Introduction to microeconomics, (Philip Allan, New York).

Layard, R., S. Nickell, and R. Jackman, 1991, Unemployment: macroeconomic performance and the labour market, (Oxford University Press, Oxford).

Lee, Y., 1999, Wages and employment in China's SOE's, 1980-1994: Corporatisation, market development and insider forces, Journal of Comparative Economics, 27, 702-729.

Leontief, W., 1946, The pure theory of the guaranteed annual wage contract, Journal of Political Economy, 54, 76-9.

Lindbeck, A., and D. Snower, 1988, The insider-outsider theory of employment and unemployment, (MIT, Cambridge Mass.).

Megginson, L. and J. Netter, 2001, From State to Market: A Survey of Empirical Studies on Privatisation, Journal of Economic Literature, 39, 321-389.

Mickiewicz, T. and M. Baltowski, 2003, All Roads Lead to Outside Ownership: Polish Piecemeal Privatisation, in: D. Parker and D. Saal, eds., International Handbook on Privatisation, (Edward Elgar, Cheltenham), 402-426.

Oswald, A., 1993, Efficient contracts are on the labour demand curve, Labour Economics, 1, 85114.

Rutkowski, J., 2002, Towards a dynamic labour market and employment growth, background paper prepared for Croatia Economic Memorandum of World Bank, mimeo.

Smolny, W., 2002, Employment adjustment at the firm level. A theoretical model and empirical investigation for West German manufacturing firms, Labour, 16, 65-88.

Vanek, J., 1970, The General theory of labour managed firms, (Cornell University Press, Ithaca New York).

Ward, B., 1958, The Firm in Illyria: Market Syndicalism, American Economic Review, 48, 56689. 
Table 2: Own wages, outside options and ownership:

\begin{tabular}{|l|c|c|}
\hline Dependent variable: $\Delta$ Employment & \multicolumn{2}{|c|}{ Specification: } \\
\hline & $(1)$ & $(2)$ \\
\hline Lagged dependent variable & $0.283(0.07)^{* * *}$ & $0.216(0.07)^{* * *}$ \\
\hline$\Delta$ Real wage & $-0.593(0.05)^{* * *}$ & $-0.596(0.06)^{* * *}$ \\
\hline$\Delta$ Real total revenue & $0.308(0.03)^{* * *}$ & $0.435(0.04)^{* * *}$ \\
\hline$\Delta$ Real sectoral wage & $0.203(0.21)$ & $0.251(0.20)$ \\
\hline$\Delta$ Real regional wage & $1.091(0.37)^{* *}$ & $1.153(0.35)^{* * *}$ \\
\hline State ownership & $-0.037(0.01)^{* *}$ & $-0.045(0.01)^{* * *}$ \\
\hline De novo ownership & $0.009(0.02)$ & $0.005(0.02)$ \\
\hline$\Delta$ Real wage * state & - & $0.122(0.09)$ \\
\hline$\Delta$ Real revenue * state & - & $-0.366(0.06)^{* * *}$ \\
\hline Service sector versus industry & $0.002(0.00)$ & $0.001(0.00)$ \\
\hline Trade sector versus other services & $-0.001(0.01)$ & $0.003(0.01)$ \\
\hline Mining \& heavy ind. versus other industry & $-0.005(0.00)^{*}$ & $-0.005(0.00)^{*}$ \\
\hline Utilities sector versus other industry & $0.008(0.00)^{* * *}$ & $0.008(0.00)^{* * *}$ \\
\hline Construction sector versus other industry & $-0.022(0.00)^{* * *}$ & $-0.022(0.00)^{* * *}$ \\
\hline Engineering sector v. other manufacturing & $-0.008(0.27)$ & $-0.008(0.27)$ \\
\hline Chemical sector v. other manufacturing & $-0.007(0.01)$ & $-0.008(0.005)$ \\
\hline Constant & $-0.010(0.02)$ & $-0.008(0.02)$ \\
\hline Second-order autocorrelation: $z$ & -0.52 & -0.77 \\
\hline Sargan test: $\chi^{2}$ & 16.41 & 11.38 \\
\hline Number of firms & 268 & 268 \\
\hline Number of observations & 670 & 670 \\
\hline
\end{tabular}

Notes:

1. Estimator: Arellano-Bond 1 step generalised method of moments.

2. $* * *$ Significant at $0.001 ; * *$ Significant at $0.01 ; *$ Significant at 0.05 ; $\uparrow$ Significant at 0.1

3. Standard errors in parentheses.

4. Time dummies included. 


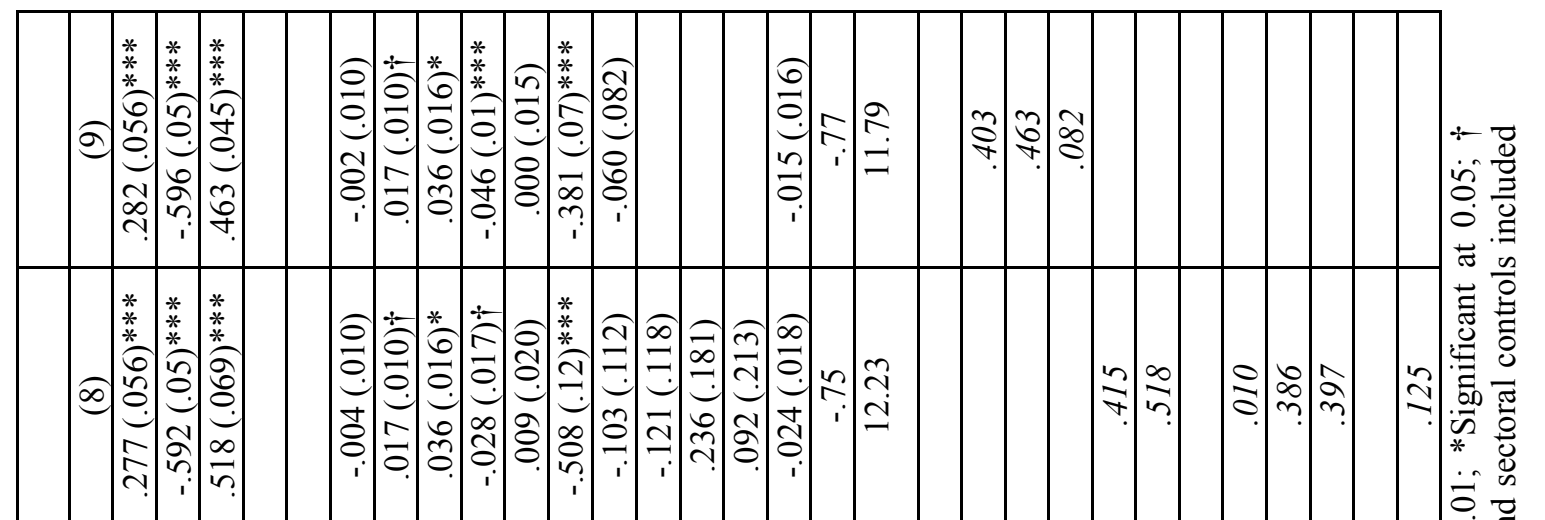

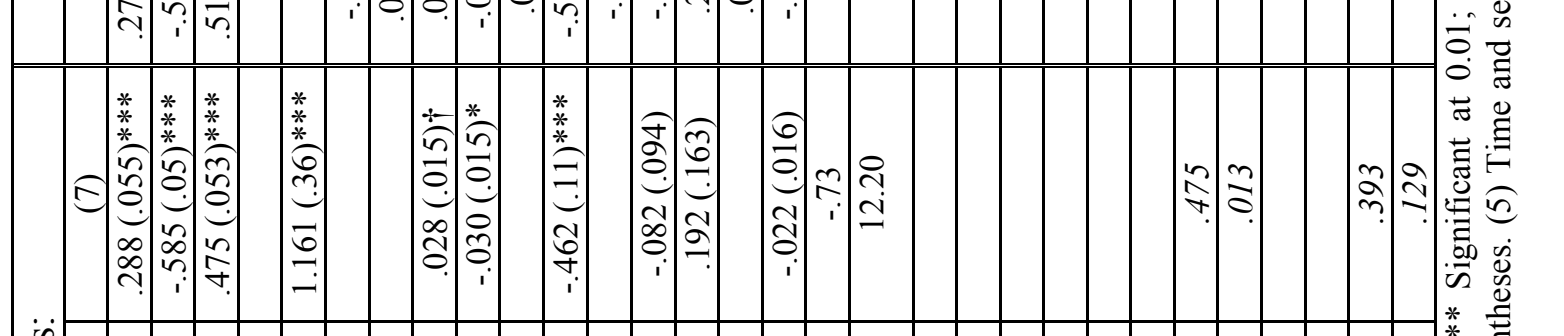

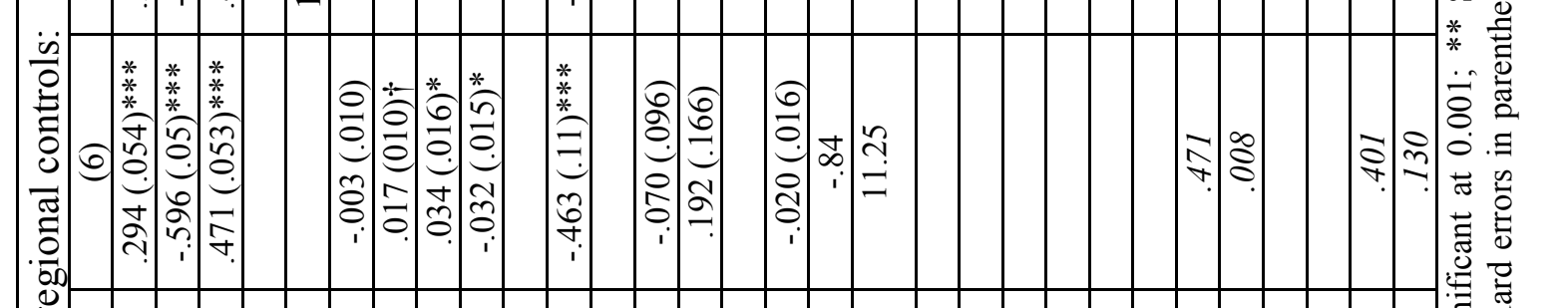

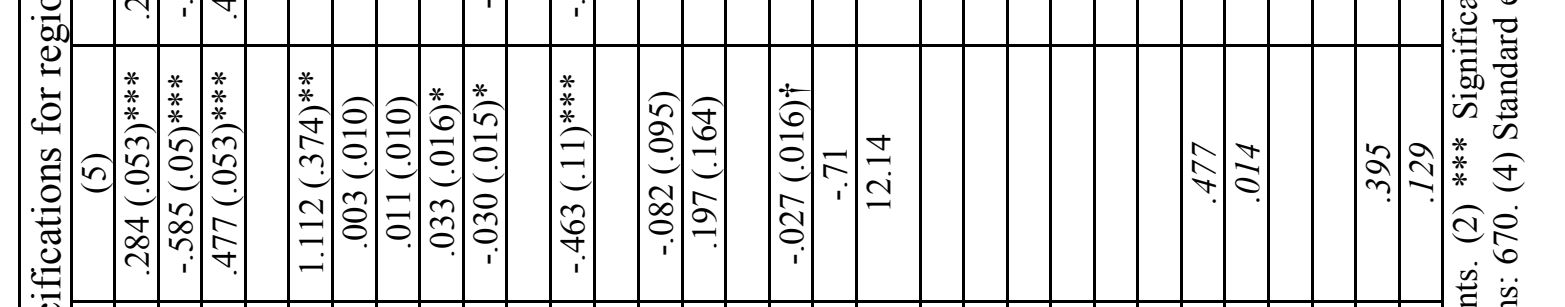

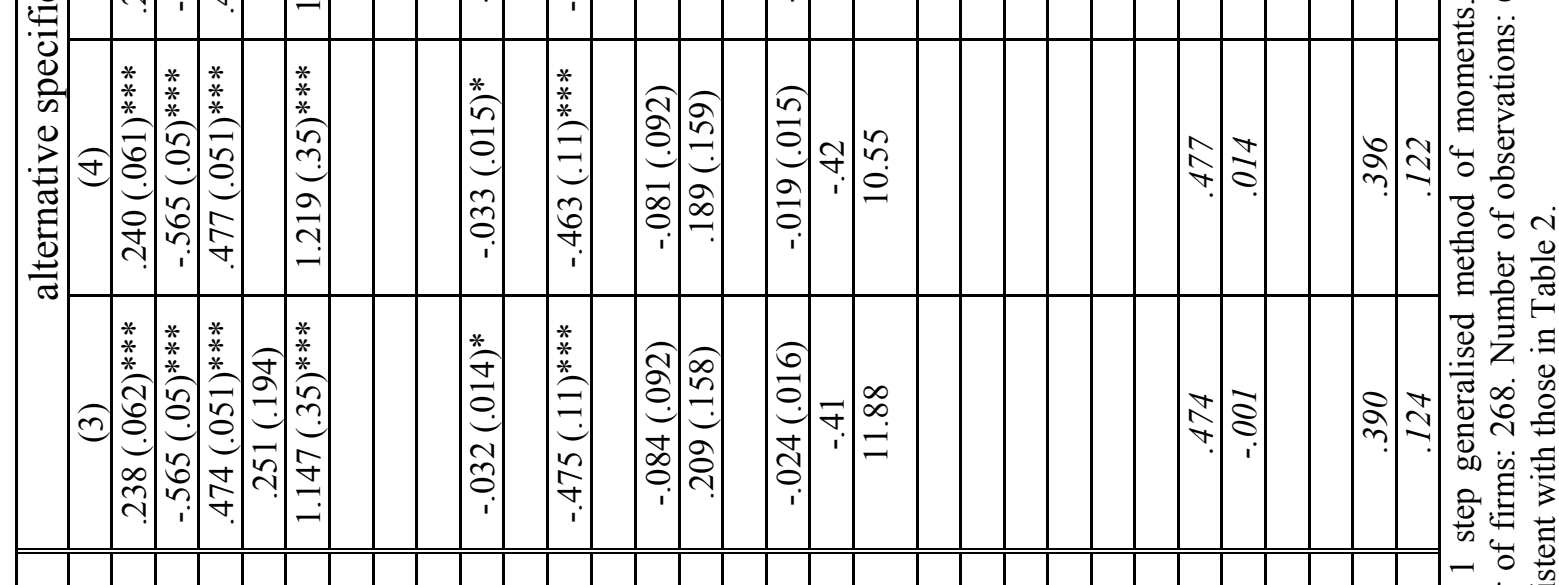

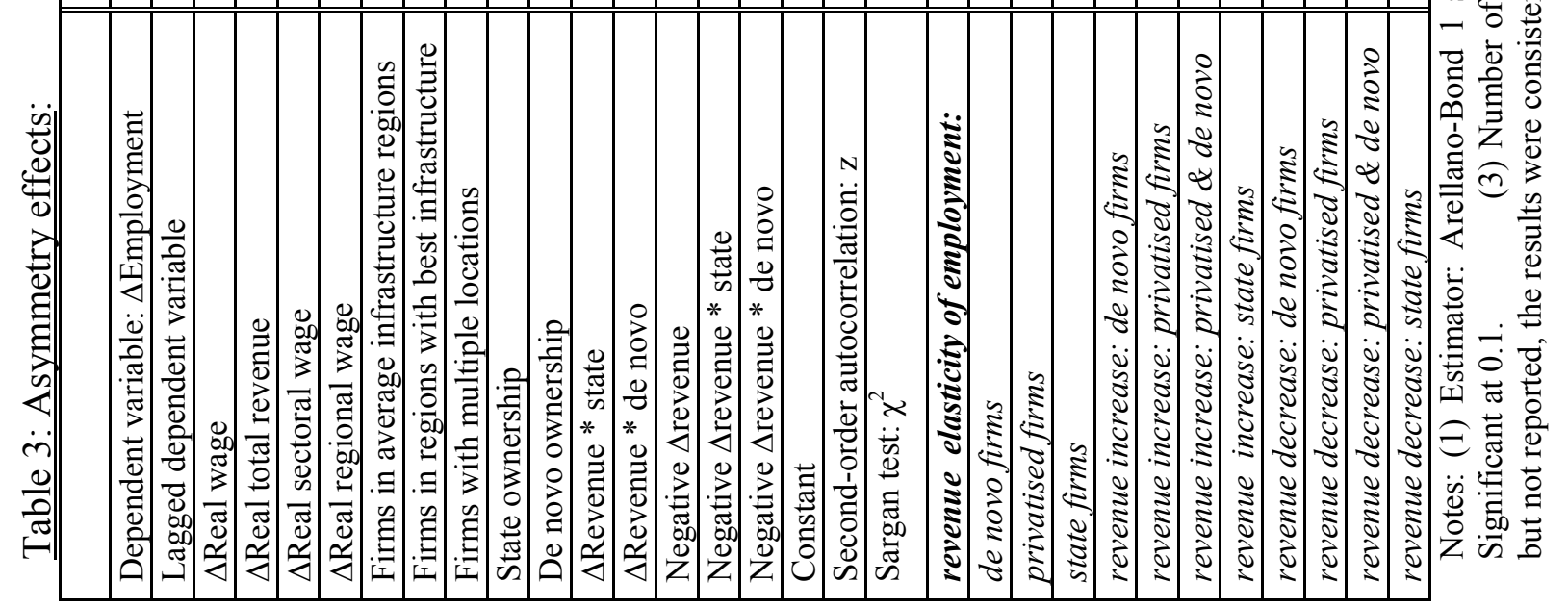




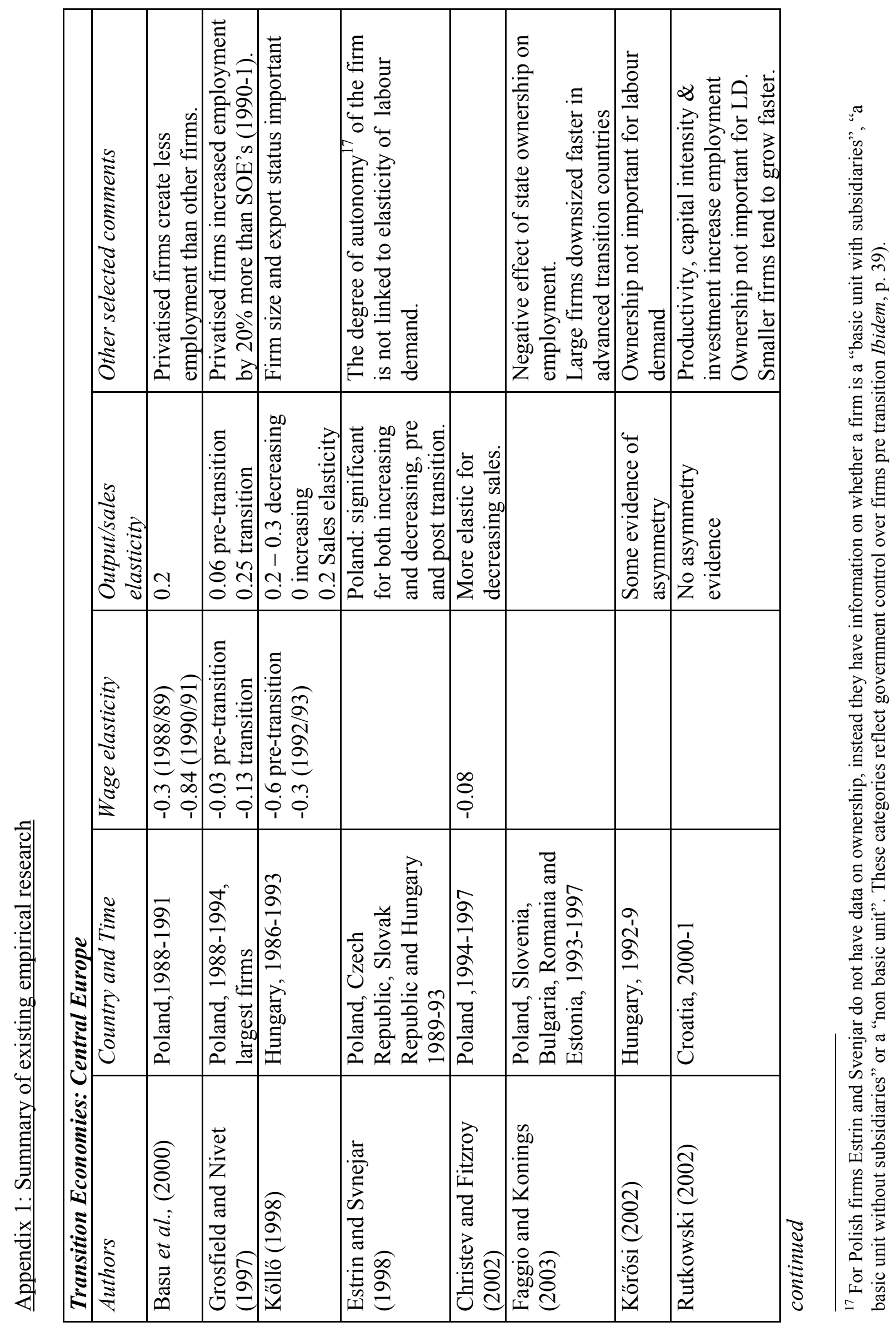




\begin{tabular}{|c|c|c|c|c|c|c|c|c|c|c|c|c|}
\hline & 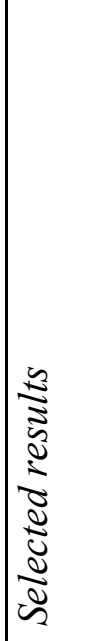 & 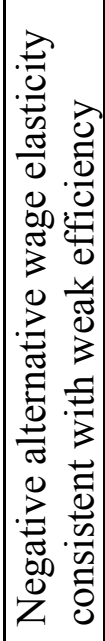 & 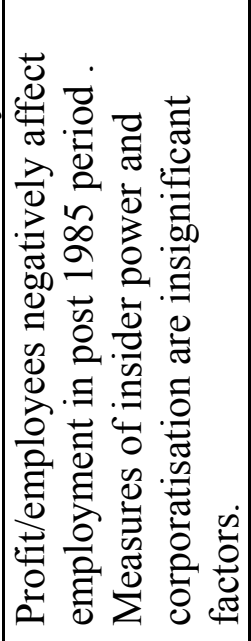 & 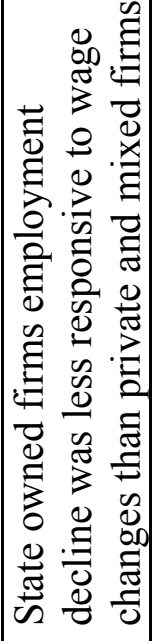 & 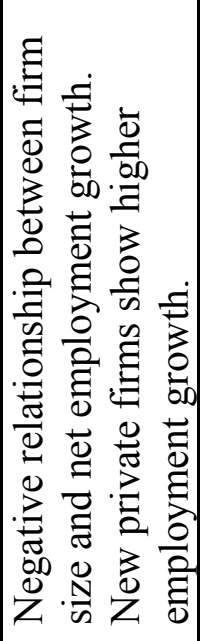 & & 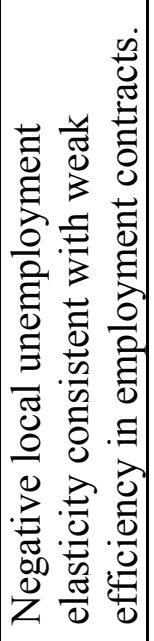 & & 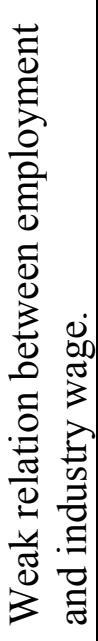 & & 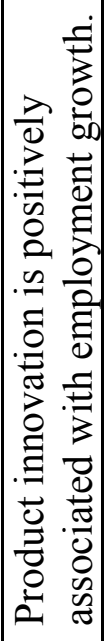 & \\
\hline & 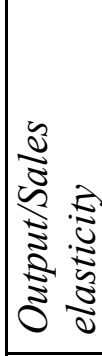 & & 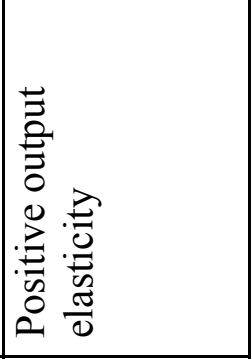 & & & & & & & 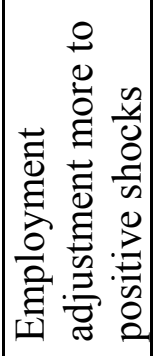 & & \\
\hline & 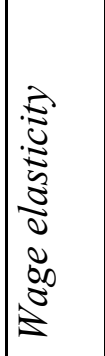 & 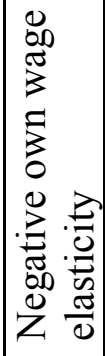 & & & & & 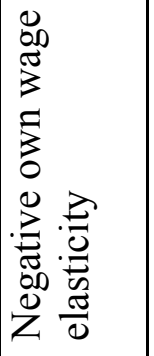 & $\begin{array}{l} \\
\\
0 \\
0 \\
0 \\
0\end{array}$ & $\begin{array}{l}\infty \\
n \\
0 \\
1 \\
0 \\
0 \\
0 \\
0 \\
1\end{array}$ & & & 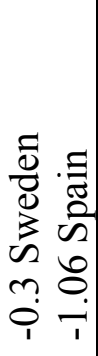 \\
\hline 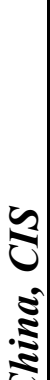 & 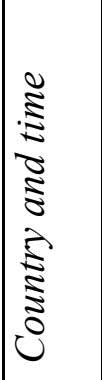 & 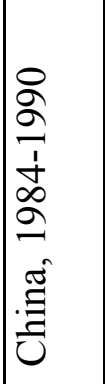 & 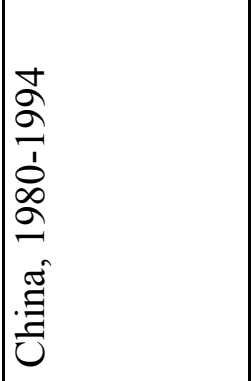 & 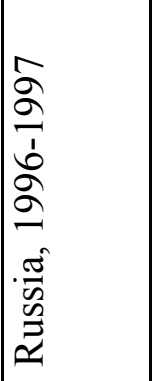 & 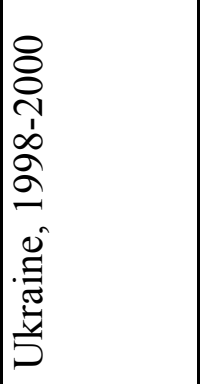 & & 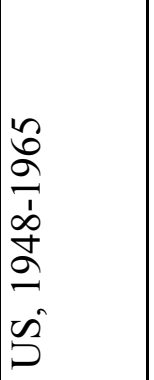 & 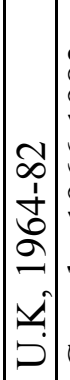 & 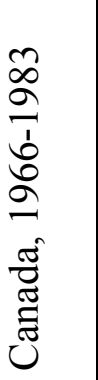 & 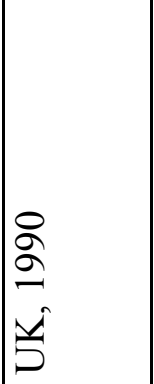 & 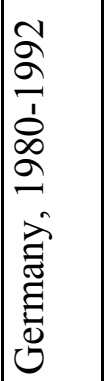 & 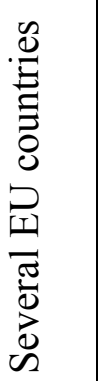 \\
\hline 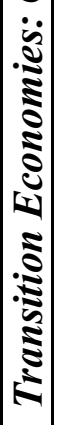 & 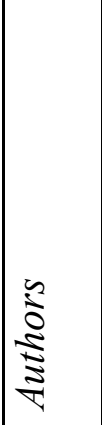 & $\begin{array}{l}20 \\
2 \\
2 \\
己 \\
0 \\
0 \\
0 \\
0 \\
0\end{array}$ & 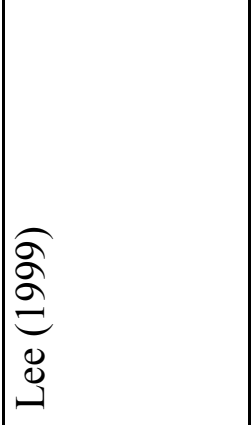 & 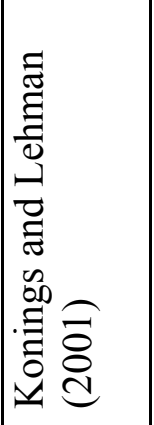 & 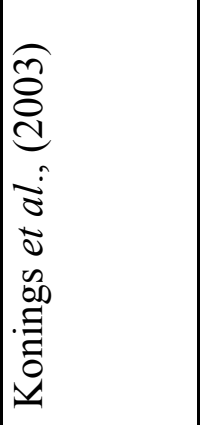 & 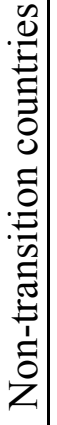 & 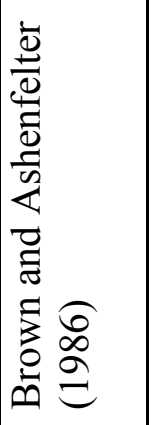 & $\begin{array}{l}0 \\
\infty \\
\infty \\
0 \\
\vdots \\
0 \\
0 \\
0 \\
\vdots \\
\infty\end{array}$ & 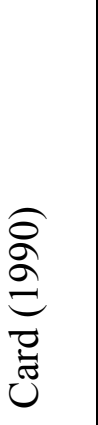 & 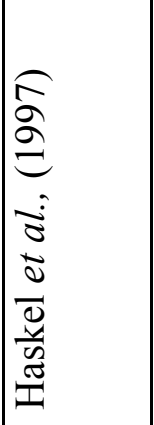 & 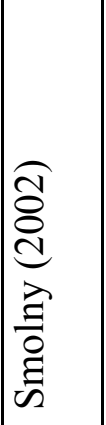 & 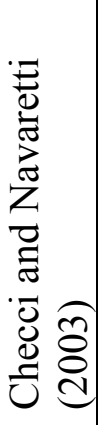 \\
\hline
\end{tabular}




\section{Appendix 2: Definition of Variables}

\begin{tabular}{|c|c|c|}
\hline Variable name & Description of variable & Details / comments \\
\hline state ownership & State owned firm (dummy, time variant) & $\begin{array}{l}\text { Contemporaneous state ownership } \\
\text { dummy }\end{array}$ \\
\hline de_novo ownership & $\begin{array}{l}\text { De novo private firm (dummy, time } \\
\text { invariant) }\end{array}$ & $\begin{array}{l}\text { A new private company, i.e. which } \\
\text { is neither state owned nor was ever } \\
\text { state owned }\end{array}$ \\
\hline privatised & Privatised firm (dummy, time variant) & $\begin{array}{l}\text { Contemporaneous privatised } \\
\text { dummy }\end{array}$ \\
\hline employment & $\begin{array}{l}\text { Natural logarithm of number of } \\
\text { employees }\end{array}$ & Available for $1996-2002$ \\
\hline real wage & Natural logarithm of real wage cost & $\begin{array}{l}\text { Ln of (average monthly wage cost } \\
\text { in zlotys/consumer price index). } \\
\text { Data 1996, 1998-2002. CPI: } \\
\text { Central Statistical Office }\end{array}$ \\
\hline real total revenue & Natural logarithm of real total revenue ${ }^{18}$ & $\begin{array}{l}\text { Total revenue/CPI. Available for } \\
\text { 1996-2002. }\end{array}$ \\
\hline$\Delta$ real total revenue & $\begin{array}{l}\text { Change in revenue given as logarithmic } \\
\text { difference (the operator } \Delta \text { has the same } \\
\text { meaning for other variables) }\end{array}$ & \\
\hline $\begin{array}{l}\Delta \text { revenue } * \text { state } \\
\text { (de novo) }\end{array}$ & $\begin{array}{l}\text { refers to the interaction of the state/de } \\
\text { novo dummy with the given variable (in } \\
\text { this example: with revenue change) }\end{array}$ & \\
\hline $\begin{array}{l}\text { negative (positive) } \\
\Delta \text { revenue }\end{array}$ & $\begin{array}{l}\text { Negative (positive) revenue growth, i.e. a } \\
\text { variable which replicates for values of } \\
\Delta \text { real total revenue }>0(<0) \text { and takes } \\
\text { zero in other cases }\end{array}$ & $\begin{array}{l}\text { By constructution, the variable } \\
\text { enables to test the differential } \\
\text { effect as compared with the source } \\
\text { variable (i.e. both } \Delta \text { real total revenue } \\
\text { and negative (positive) } \Delta \text { revenue } \\
\text { should be included in any given } \\
\text { specification) }\end{array}$ \\
\hline $\begin{array}{l}\text { negative (positive) } \Delta \\
\text { revenue * state (de } \\
\text { novo) }\end{array}$ & $\begin{array}{l}\text { The variable defined in the previous row } \\
\text { multiplied by the state (de novo) dummy }\end{array}$ & \\
\hline
\end{tabular}

continued

\footnotetext{
${ }^{18} \mathrm{We}$ also have data on sales. Sales could be a better measure, i.e. more related to outcome from operations, but the data is less complete for that variable and correlation between sales and revenues is very close to one. Therefore, we opt for revenues. Estimations based on sales are available on request.
} 


\begin{tabular}{|c|c|c|}
\hline Variable name & Description of variable & Details / comments \\
\hline Year controls & 1999, 2000, 2001 dummies & $\begin{array}{l}\text { Four years allowed given the } \\
\text { GMM lag structure }\end{array}$ \\
\hline Sectoral controls & 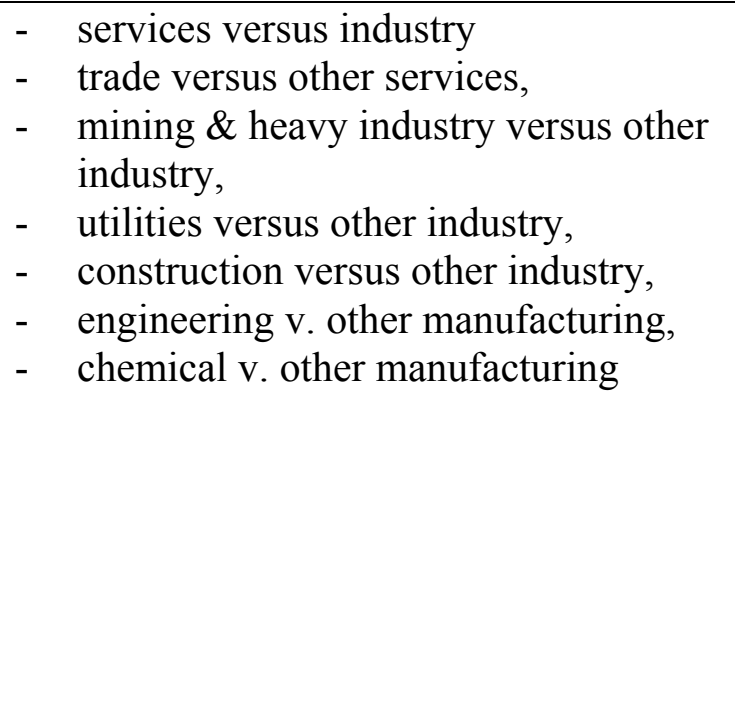 & $\begin{array}{l}\text { Sectoral controls are constructed } \\
\text { as orthogonal contrasts. When } \\
\text { replaced by simple dummies, the } \\
\text { results do not change. However, } \\
\text { using orthogonal contrasts allows } \\
\text { the sectoral controls to be } \\
\text { uncorrelated with each other. } \\
\text { Moreover, instead of being } \\
\text { constructed as the difference } \\
\text { against one benchmark group, the } \\
\text { orthogonal contrasts allow } \\
\text { describing the structure of sectoral } \\
\text { differences in a more reach way. } \\
\text { Details of coding are available on } \\
\text { request. }\end{array}$ \\
\hline \multicolumn{3}{|l|}{$\begin{array}{l}\text { External } \\
\text { characteristics }\end{array}$} \\
\hline real sectoral wage & Logarithm of real sectoral wages & $\begin{array}{l}\text { Logarithm of (average monthly } \\
\text { wage in zlotys/CPI). Available for } \\
\text { 1996-2001, two digit NACE } \\
\text { sectors }\end{array}$ \\
\hline real regional wage & Logarithm of real regional wage & $\begin{array}{l}\text { Central Statistical Office data. At } \\
\text { the provincial level; } 17 \text { (new) } \\
\text { provinces. Annual average. } \\
\text { Available 1998-2001 }\end{array}$ \\
\hline poor infrastructure & $\begin{array}{l}\text { Categories I-IV of the taxonomy of public } \\
\text { infrastructure of Polish regions (based on } \\
49 \text { regions) }\end{array}$ & \multirow{3}{*}{$\begin{array}{l}\text { Based directly on Duffy and } \\
\text { Walsh (2001), which offers } \\
\text { detailed description; clustering of } \\
\text { categories I-IV in our sample } \\
\text { results from the fact that there was } \\
\text { a small number of companies in } \\
\text { each of the four; } \\
\text { Ranking is constructed in such a } \\
\text { way that category VI corresponds } \\
\text { to best infrastructure }\end{array}$} \\
\hline $\begin{array}{l}\text { average } \\
\text { infrastructure }\end{array}$ & Category V & \\
\hline best infrastructure & Category VI & \\
\hline multiple locations & $\begin{array}{l}\text { Dummy for companies operating } \\
\text { nationwide }\end{array}$ & $\begin{array}{l}\text { Companies within this category } \\
\text { were not assigned to any } \\
\text { infrastructure category. In other } \\
\text { words this and the previous three } \\
\text { categories are mutually exclusive }\end{array}$ \\
\hline
\end{tabular}




\section{DAVIDSON INSTITUTE WORKING PAPER SERIES - Most Recent Papers}

The entire Working Paper Series may be downloaded free of charge at: www.wdi.bus.umich.edu

CURRENT AS OF 7/7/03

\begin{tabular}{|c|c|c|}
\hline Publication & Authors & Date \\
\hline $\begin{array}{l}\text { No. 593: While Labour Hoarding May Be Over, Insiders' Control Is } \\
\text { Not. Determinants of Employment Growth in Polish Large Firms, } \\
\text { 1996-2001 }\end{array}$ & $\begin{array}{l}\text { Kate Bishop and Tomasz } \\
\text { Mickiewicz }\end{array}$ & July 2003 \\
\hline $\begin{array}{l}\text { No. 592: Globalization and Trust: Theory and Evidence from } \\
\text { Cooperatives }\end{array}$ & $\begin{array}{l}\text { Ramon Casadesus-Masanell and } \\
\text { Tarun Khanna }\end{array}$ & June 2003 \\
\hline $\begin{array}{l}\text { No. 591: Restructuring or Disintegration of the German Corporate } \\
\text { Network: Globalization as a Fifth Column }\end{array}$ & Bruce Kogut and Gordon Walker & June 2003 \\
\hline $\begin{array}{l}\text { No. 590: Institutional Change and Firm Creation in East-Central } \\
\text { Europe: An Embedded Politics Approach }\end{array}$ & Gerald A. McDermott & June 2003 \\
\hline $\begin{array}{l}\text { No. 589: Legitimacy, Interest Group Pressure and Institutional Change: } \\
\text { The Case of Foreign Investment and Host Country Governments }\end{array}$ & $\begin{array}{l}\text { Witold J. Henisz and Bennet A. } \\
\text { Zelner }\end{array}$ & June 2003 \\
\hline $\begin{array}{l}\text { No. 588: Institutions and the Vicious Circle of Distrust in the Russian } \\
\text { Household Deposit Market, 1992-1999 }\end{array}$ & Andrew Spicer and William Pyle & June 2003 \\
\hline $\begin{array}{l}\text { No. 587: Foreign Direct Investment and the Business Environment in } \\
\text { Developing Countries: the Impact of Bilateral Investment Treaties }\end{array}$ & $\begin{array}{l}\text { Jennifer Tobin and Susan Rose- } \\
\text { Ackerman }\end{array}$ & June 2003 \\
\hline No. 586: Trust in China: A Cross-Regional Analysis & Rongzhu Ke and Weiying Zhang & June 2003 \\
\hline No. 585: Family Control and the Rent-Seeking Society & $\begin{array}{l}\text { Randall Morck and Bernard } \\
\text { Yeung }\end{array}$ & June 2003 \\
\hline $\begin{array}{l}\text { No. 584: Wage Determination: Privatised, New Private and State } \\
\text { Owned Companies, Empirical Evidence from Panel Data }\end{array}$ & $\begin{array}{l}\text { Tomasz Mickiewicz and Kate } \\
\text { Bishop }\end{array}$ & June 2003 \\
\hline No. 583: An Investigation of Firm-Level R\&D Capabilities in East Asia & $\begin{array}{l}\text { Gary H. Jefferson and Zhong } \\
\text { Kaifeng }\end{array}$ & June 2003 \\
\hline $\begin{array}{l}\text { No. 582: R\&D and Technology Transfer: Firm Level Evidence From } \\
\text { Chinese Industry }\end{array}$ & $\begin{array}{l}\text { Albert G.Z. Hu, Gary H. } \\
\text { Jefferson, Guan Xiaojing and } \\
\text { Qian Jinchang }\end{array}$ & June 2003 \\
\hline $\begin{array}{l}\text { No. 581: Credit Market Disequilibrium in Poland: Can We Find } \\
\text { What We Expect? Non-Stationarity and the "Min", } \\
\text { Condition }\end{array}$ & $\begin{array}{l}\text { Christophe Hurlin } † \text { and Rafal } \\
\text { Kierzenkowski }\end{array}$ & June 2003 \\
\hline $\begin{array}{l}\text { No. 580: Does it Take a Lula to go to Davos? } \\
\text { A Brief Overview of Brazilian Reforms, 1980-2000 }\end{array}$ & $\begin{array}{l}\text { Nauro F. Campos, Armando } \\
\text { Castellar Pinheiro, Fabio } \\
\text { Giambiagi and Maurício M. } \\
\text { Moreira }\end{array}$ & June 2003 \\
\hline $\begin{array}{l}\text { No. 579: Ceaseless Toil? Health and Labor Supply of the Elderly in } \\
\text { Rural China }\end{array}$ & $\begin{array}{l}\text { Dwayne Benjamin, Loren Brandt } \\
\text { and Jia-Zhueng Fan }\end{array}$ & June 2003 \\
\hline $\begin{array}{l}\text { No. 578: Shadow Economy, Rent-Seeking Activities and the Perils of } \\
\text { Reinforcement of the Rule of Law }\end{array}$ & Ekaterina Vostroknutova & June 2003 \\
\hline $\begin{array}{l}\text { No. 577: No Pain, No Gain: Market Reform, Unemployment, and } \\
\text { Politics in Bulgaria }\end{array}$ & Neven Valev & June 2003 \\
\hline $\begin{array}{l}\text { No. 576: Power Analysis of the Nice Treaty On the Future of European } \\
\text { Integration }\end{array}$ & Yener Kandogan & June 2003 \\
\hline $\begin{array}{l}\text { No. 575: Democracy’s Spread: Elections and Sovereign Debt in } \\
\text { Developing Countries }\end{array}$ & $\begin{array}{l}\text { Steven A. Block, Burkhard N. } \\
\text { Schrage, and Paul M. Vaaler }\end{array}$ & June 2003 \\
\hline $\begin{array}{l}\text { No. 574: Reintroducing Intergenerational Equilibrium: Key Concepts } \\
\text { Behind the New Polish Pension System }\end{array}$ & Marek Góra & June 2003 \\
\hline $\begin{array}{l}\text { No. 573: Why Does FDI Go Where It Goes? New Evidence From the } \\
\text { Transition Economies }\end{array}$ & $\begin{array}{l}\text { Yuko Kinoshita and Nauro F. } \\
\text { Campos }\end{array}$ & June 2003 \\
\hline $\begin{array}{l}\text { No. 572: Private Savings in Transition Economies: Are There Terms of } \\
\text { Trade Shocks? }\end{array}$ & Abdur R. Chowdhury & May 2003 \\
\hline $\begin{array}{l}\text { No. 571: On the long-run determinants of real exchange rates for } \\
\text { developing countries: Evidence from Africa, Latin America and Asia }\end{array}$ & Imed Drine and Christophe Rault & May 2003 \\
\hline $\begin{array}{l}\text { No. 570: A re-examination of the Purchasing Power Parity using non- } \\
\text { stationary dynamic panel methods: a comparative approach for } \\
\text { developing and developed countries }\end{array}$ & Imed Drine and Christophe Rault & May 2003 \\
\hline
\end{tabular}

